\title{
A audiência pública sobre quotas raciais no Supremo Tribunal Federal ${ }^{1-2-3}$
}

\author{
The public hearing on racial quotas at the Brazilian Supreme Court

\section{La audiencia pública sobre cuotas raciales en la Corte Suprema brasileña}

\author{
Marjorie Marona ${ }^{4}$ \\ Universidade Federal de Minas Gerais (Belo Horizonte, MG, Brasil) \\ ORCID: https://orcid.org/0000-0002-6820-2210 \\ E-mail: maronamarjorie@gmail.com \\ Luciana Andrade ${ }^{5}$ \\ Universidade Federal de Minas Gerais (Belo Horizonte, MG, Brasil) \\ ORCID: https://orcid.org/0000-0002-2881-1011 \\ E-mail: alucianandrade@gmail.com
}

\section{Resumo}

O fortalecimento institucional do Supremo Tribunal Federal (STF) e certo ativismo judicial reverberaram a expectativa de parte da literatura acerca da capacidade de estímulo ao diálogo político e social até bem pouco tempo. O estudo das audiências públicas (APs) no STF pode lançar luz sobre esse debate,

\footnotetext{
${ }^{1}$ MARONA, Marjorie Corrêa; ANDRADE, Luciana Vieira Rubim. A audiência pública sobre quotas raciais no Supremo Tribunal Federal. Suprema: revista de estudos constitucionais, Brasília, v. 1, n. 2, p. 257-289, jul./dez. 2021.

2 Este artigo foi produzido como resultado (parcial) do projeto de pesquisa "Deliberação e Cortes Constitucionais: as Audiências Públicas no STF”, que conta com o auxílio financeiro do Conselho Nacional de Desenvolvimento Científico e Tecnológico (CNPq) (MCTI/CNPq No 01/2016).

3 Agradecemos as contribuições do professor João Feres Jr. (IESP/UERJ) e os comentários às versões anteriores, apresentadas no Seminário Temático Juristas, instituições judiciais e disputas sobre o direito, no $43^{\circ}$ Encontro Anual da Associação Nacional de Pós-Graduação e Pesquisa em Ciências Sociais (ANPOCS). Agradecemos também aos pareceristas anônimos da Suprema - Revista de Estudos Constitucionais.

4 Doutora em Ciência Política pela Universidade Federal de Minas Gerais (UFMG), onde atua como professora e pesquisadora do Departamento de Ciência Política e Programa de Pós-Graduação em Ciência Política. Coordenadora do Observatório da Justiça no Brasil e na América Latina (OJb-AL), núcleo de pesquisa da UFMG. Currículo Lattes: http://lattes.cnpq.br/0414801887136245.

${ }^{5}$ Doutora em Ciência Política pela Universidade Federal de Minas Gerais. Pesquisadora do Núcleo de Estudos e Pesquisas sobre a Mulher (Nepem) e do Observatório da Justiça no Brasil e na América Latina (OJb-AL), ambos da UFMG. Currículo Lattes: http://lattes.cnpq.br/9966017156232841.
} 
tomando como pressuposto seu potencial para articular o diálogo interinstitucional e com a opinião pública. Centrados na relação entre o STF e a opinião pública, analisamos a capacidade do STF de mobilizar a "AP das quotas raciais" para inserir-se no debate público, a partir de uma comparação sistemática entre atores e argumentos fomentados pela mídia. Utilizamos a análise de conteúdo da AP e dos textos jornalísticos e procedemos à identificação dos diferentes atores com voz no debate público, considerando os dois espaços. Os resultados reforçam o viés de cobertura da mídia brasileira, já identificado em trabalhos anteriores, mas não confirmam o potencial das APs identificado pela literatura.

\section{Palavras-chave}

Audiências públicas; Quotas raciais; Supremo Tribunal Federal; Opinião pública.

\section{Suimário}

1. Introdução. 2. Metodologia. 3. Análise de dados. 4. Conclusão.

\section{Abstract}

The institutional strengthening of the Brazilian Supreme Court (Supremo Tribunal Federal - STF) and certain judicial activism reverberated the expectation of part of the literature about the capacity to stimulate political and social dialogue until very recently. The STF's Public Hearings research can shed light on this debate, assuming its potential to articulate interinstitutional dialogue and public opinion. Focused on the relationship between the Brazilian Supreme Court and public opinion, we analyzed the STF's ability to mobilize the "racial quotas public hearing" to enter the public debate, based on a systematic comparison between actors and arguments mobilized by the media. We used the public hearing and the journalistic texts' content analysis and proceeded to identify the different actors with a voice in the public debate, considering the two spaces. The results reinforce the Brazilian media coverage bias already identified in previous works, but it does not confirm the potential of public hearings identified by the literature.

\section{Keywords}

Public hearings; Racial quotas; Brazilian Supreme Court; Public opinion.

\section{Contents}

1. Introducion. 2. Method. 3. Data analysis. 4. Final Remarks. 


\section{Resumen}

El fortalecimiento institucional del STF y un cierto activismo judicial repercutieron en la expectativa de parte de la literatura sobre la capacidad para estimular el diálogo político y social hasta hace muy poco. El estudio de los PA en el STF puede arrojar luz sobre este debate, asumiendo su potencial para articular el diálogo interinstitucional y la opinión pública. Enfocados en la relación entre STF y opinión pública, analizamos la capacidad del STF para movilizar la "cuota racial AP” para insertarse en el debate público, a partir de una comparación sistemática entre actores y argumentos movilizados por los medios de comunicación. Utilizamos el análisis de contenido de la AP y los textos periodísticos y procedimos a identificar a los diferentes actores con voz en el debate público, considerando los dos espacios. Los resultados refuerzan el sesgo de cobertura de los medios brasileños ya identificado en trabajos anteriores, pero no confirman el potencial de los AP, identificado por la literatura.

\section{Palabras clave}

Audiencias públicas; Cuotas raciales; Supremo Tribunal Federal; Opinión pública.

\section{Índice}

1. Introducción. 2. Metodología. 3. Análisis de datos. 4. Reflexiones Finales.

\section{Introdução}

Realizadas pelo Supremo Tribunal Federal (STF) desde 2007, as audiências públicas (APs) constituem uma inovação institucional que passou imediatamente a receber a atenção dos estudiosos do judicial politics no Brasil (ARIEDE, 2011; BARBOSA, PAMPLONA, 2009; BENEDETTI, SÁENZ, 2016; FRAGALE FILHO, 2015; LEITE, 2015; LIMA, 2008; MARONA, ROCHA, 2014, 2017; MEDINA, FREIRE, 2013; PESSOA, 2012; SILVA, AJOUZ, 2013; SOMBRA, 2017; VESTENA, 2012).

No Poder Judiciário, a previsão de APs no âmbito da jurisdição constitucional remete à publicação da Lei 9.868/1999, que regulamenta a Ação Direta de Inconstitucionalidade (ADI) e a Ação Declaratória de Constitucionalidade (ADC), e foi referida também na Lei 9.882/1999, que trata da Arguição de Descumprimento de Preceito Fundamental (ADPF).Com isso, estabeleceu-se a previsão de realização de APs no âmbito do exercício do controle concentrado de constitucionalidade, por convocação do presidente da Corte ou do relator 
do processo e com a participação de membros da sociedade civil, para fins de esclarecimento de matéria ou circunstância de fato.

A realização das APs no STF acompanhou seu crescente protagonismo e envolveu o debate acerca da compatibilidade de sua atuação com o princípio democrático, revelando a dificuldade contramajoritária (BICKEL, 1986). Avançando em direção das considerações deliberacionistas de democracia, as cortes foram tomadas ora como o lócus da razão pública (DWORKIN, 2001, 2007, 2010), ora como um interlocutor institucional (BATEUP, 2006; MENDES, 2009), ora como agentes deliberativos (FEREJOHN; PASQUINO, 2002, 2003). Por outro lado, o reconhecimento de que há vida constitucional para além das cortes (FRIEDMAN, 2009; HÄBERLE, 2003) trouxe a expectativa em torno da sua capacidade de estimular o diálogo político e social, emprestando novos contornos à questão da legitimidade democrática das cortes (WOOLMAN; BISHOP, 2008).

Essa é uma questão particularmente sensível para a democracia brasileira, considerando a saliência política adquirida pelo STF (HIRSCHL, 2009). Nesses termos, as APs realizadas pela Corte no exercício da jurisdição constitucional poderiam representar uma inovação institucional democrática (PIRES; VAZ, 2012 , 2014), capazes de promover o realinhamento do debate acerca da legitimidade das cortes constitucionais, considerando a tripla natureza do instituto: como um mecanismo de deliberação interna e interinstitucional (TULIS, 2003; WOOLMAN; BISHOP, 2008) e como um canal de interligação e mútua influência entre Estado, sociedade civil e sociedade. Neste último caso, as APs conformariam uma espécie de interface socioestatal: um espaço político estabelecido intencionalmente entre atores, cujos resultados podem gerar tanto implicações coletivas quanto estritamente individuais (ISUNZA; DE LA JARA, 2006), impactando a agenda pública nacional em articulação com a mídia.

Tendo como base, portanto, a miríade de debates acerca da legitimidade democrática do Supremo Tribunal Federal é que pretendemos realizar as análises da Audiência Pública sobre as Quotas Raciais, especificamente. Ressaltamos a máxima importância política e social da questão desenvolvida em deliberações, com a convocação de diferentes especialistas e amicus curiae e a intensa publicização da audiência ao longo de sua realização pela mídia brasileira. Entendemos que há aqui a oportunidade de analisar uma possível ampliação democrática brasileira por diferentes vieses: institucional, deliberacionista, judicial e de representação política. 
Neste artigo, analisamos uma audiência pública em particular: aquela realizada entre os dias 3 e 5 de março de 2010, no âmbito do julgamento da Arguição de Descumprimento de Preceito Fundamental (ADPF) 186, proposta pelo Partido Democratas (DEM) para contestar a constitucionalidade do programa de ação afirmativa de recorte racial da Universidade de Brasília (UnB) e, consequentemente, da aplicação desse tipo de política em todo o País. A audiência também foi destinada a discutir o Recurso Extraordinário 597.285, sendo este o caso concreto de Giovane Pasqualito Fialho contra o sistema de quotas com reserva de vagas para estudantes de escolas públicas da Universidade Federal do Rio Grande do Sul.

No momento da propositura da primeira ação, em julho de 2009, políticas afirmativas étnico-raciais vigiam em mais da metade das universidades públicas brasileiras (FERES JÚNIOR, 2008; 2010). O texto da ADPF proposta pelo DEM estava prenhe de referências a textos jornalísticos acerca das políticas de ação afirmativa, boa parte deles escritos por acadêmicos que reclamavam para si o reconhecimento de sua autoridade sobre o tema das relações raciais no Brasil (FERES JÚNIOR; DAFLON; CAMPOS, 2010).

O Ministro Ricardo Lewandowski foi sorteado para relatar a ação. Em seguida, o STF convocou uma audiência pública para instruir a Corte sobre o assunto, que se realizou em março de 2010. Foram três dias de apresentações de especialistas e representantes da sociedade civil interessados pelo tema, com um total de 38 palestrantes. Em 2012, a Corte se reuniu para deliberar sobre o caso, com a vitória por unanimidade do relatório de Lewandowski defendendo a plena constitucionalidade da ação afirmativa racial, a despeito dos vários argumentos contrários elencados na ADPF.

A decisão do STF foi festejada pelo movimento negro como uma grande vitória da agenda da igualdade racial no Brasil. É inegável que a decisão do STF contribuiu para dar estabilidade legal e maior legitimidade às políticas de ação afirmativa. Além disso, abriu caminho para a aprovação da Lei de Quotas no mesmo ano, e foi fator fundamental de mitigação do debate na mídia, como constatado por alguns estudos (CAMPOS; FERES JÚNIOR, 2013). Mas seria possível afirmar que a atuação do STF - e particularmente a AP que foi realizada no âmbito do processo - tenha contribuído para a qualificação do debate público sobre o tema? 
Desde o início da década de 2000, a imprensa vinha conduzindo o debate público acerca da política afirmativa racial no Brasil. De fato, com o advento das primeiras políticas de ação afirmativa racial na Universidade do Estado do Rio de Janeiro (UERJ), a grande imprensa, liderada pelo jornal O Globo, deu início a um caloroso debate sobre a propriedade da adoção de tais políticas, mobilizando uma pletora de atores sociais e de justificações públicas (CAMPOS; FERES JÚNIOR, 2013; DAFLON; FERES JÚNIOR, 2012).

Como material empírico neste trabalho foram utilizadas todas as matérias relacionadas ao tema da audiência pública publicadas nos jornais O Globo e a Folha de São Paulo, além das notas taquigráficas da própria audiência pública e do acórdão com a decisão do julgamento. O texto que se segue apresenta a metodologia adotada nesta pesquisa e, posteriormente, os principais achados. Por fim, as conclusões e expectativas para a formação de uma agenda de pesquisa. Nos anexos podem ser consultadas informações detalhadas acerca dos achados aqui apresentados.

\section{Metodologia}

No que toca ao material jornalístico, analisamos todas as matérias sobre o tema das ações afirmativas publicadas nos jornais O Globo e Folha de São Paulo de 2001 a 2012, período que engloba o surgimento das políticas de quotas até a decisão de sua constitucionalidade pelo STF. Para efeito de comparação, examinamos as notas taquigráficas da audiência pública, com a transcrição de todas as falas e intervenções ao longo dos três dias de audiência, e o acórdão com a decisão do julgamento, disponibilizado pelo Supremo Tribunal Federal. Nele há, na íntegra, o voto do Ministro Ricardo Lewandowski e os votos de todos os demais ministros que participaram do julgamento: Marco Aurélio, Gilmar Mendes, Joaquim Barbosa, Cármen Lúcia, Luiz Fux e Rosa Weber.

A votação ocorreu de forma unânime. No entanto, como poderá ser visto nos dados que se seguem, é importante analisar os argumentos desenvolvidos ao longo da sessão no STF. Em algumas falas dos ministros, há apresentação de argumentos contrários às quotas, como, por exemplo, a necessidade de que outras políticas fossem incluídas. Ademais, analisar o acórdão com os votos dos ministros é uma etapa importante para a averiguação de se (e como) houve inserção do debate ocorrido na audiência pública nessa instância decisória. 
Por meio da comparação das justificações pro e contra e dos atores envolvidos na AP e na mídia, pretendemos avaliar se a AP trouxe ganhos qualitativos, em termos de publicidade, tornando mais plurais as vozes e os argumentos constitutivos do debate. A metodologia adotada é a de análise de conteúdo, que nos permite identificar, de forma qualitativa, os argumentos, as percepções e as opiniões apresentadas ao longo da audiência pública, bem como dos votos proferidos no momento do julgamento. Dessa forma, superamos uma simples análise dicotômica de "sim ou não" sobre a necessidade das quotas raciais para uma avaliação mais robusta acerca da conformação da decisão final e como esta foi construída nesses espaços formais de deliberação e também de representação. Ademais, como poderá ser observado, a análise de conteúdo também nos possibilita quantificar informações como forma de obter também um panorama geral de temas importantes, como a questão da igualdade de gênero e a participação de mulheres em espaços decisórios.

A análise de conteúdo é uma metodologia que se caracteriza pela sua versatilidade, a partir de um conjunto de vias possíveis, embasadas na reconstrução dos sentidos e dos significados dos documentos disponíveis. A gama de fontes que pode ser utilizada é extensa. Documentos históricos, materiais didáticos, filmes, novelas, entre outros, são importantes fontes analíticas e instrumentos que reproduzem entendimentos de uma conjuntura, sobre determinados grupos. Os procedimentos comumente adotados nas pesquisas de análise de conteúdo seguem as etapas de recorte do conteúdo, definição de categorias analíticas e categorização final das unidades de análise (LAVILLE; DIONNE, 1999).

A categorização das razões foi feita a partir da Grounded Theory. Procedemos da seguinte forma: a partir de uma primeira codificação, que buscava identificar os argumentos da maneira como eles aparecem nos textos, realizamos seguidas agregações de modo a propor categorias com progressivo grau de generalidade e, portanto, relevância teórica. Esse é um processo dialógico, de ida e vinda dos dados à teoria, que se mostra frutífero para a construção de reflexões teóricas não desvinculadas da realidade que buscam explicar. Isso porque o processo de conhecimento e transformação dos dados em significado e símbolo é feito indutivamente, a partir dos próprios dados (CHARMAZ, 2008).

Inicialmente, coletamos todo o material disponibilizado pelo Supremo Tribunal Federal e realizamos uma primeira leitura para conhecimento e apropriação do material. Em diálogo com toda a literatura especializada do tema e também com o que já havia sido identificado na primeira leitura, elaboramos 
categorias úteis para análise, como, por exemplo, a representação da política de quotas na fala dos participantes, e se essa fala se enquadrava em um posicionamento progressista em termos de garantia de direitos e ampliação democrática. Posteriormente, a partir dessas categorias e com o auxílio do Software NVivo, em sua versão 11, prosseguimos para a fase de codificação de todos os textos e, em seguida, para a sua análise.

Importante ressaltar que todas as etapas seguidas não são momentos estáticos de uma pesquisa nem foram feitas de forma isolada. Na análise de conteúdo foi necessária a imersão de todas as pesquisadoras no tema e no material para que houvesse, por exemplo, a concordância de que as categorias estavam realmente representando o que se buscou explicar. Em seguida apresentaremos nossa análise dos dados.

\section{Análise dos dados}

Iniciando por observar os atores e as vozes, constata-se que diversos grupos tiveram voz ativa na "AP das quotas raciais". A maioria dos participantes da audiência pública eram representantes da burocracia estatal brasileira, conforme demonstrado no gráfico 1. Dentre esses burocratas constam reitores, vice-reitores, pró-reitores, juízes, ministros de Estado, diretores de instituto de pesquisa, advogados, entre outros. No entanto, as vozes mais ouvidas na audiência pública foram as do campo científico, acadêmico e intelectual.

Com forte presença, os intelectuais e outros representantes de universidades e institutos científicos foram também majoritariamente mobilizados indiretamente, isto é, como fontes citadas nos discursos. Interessante observar, ainda, que, embora a presença de políticos (representantes eleitos) tenha sido reduzida, eles figuraram indiretamente como vozes importantes no debate público. Já os representantes de movimentos sociais e de organizações não governamentais (ONGs), incluídas aí as religiosas, foram vozes minoritárias. 


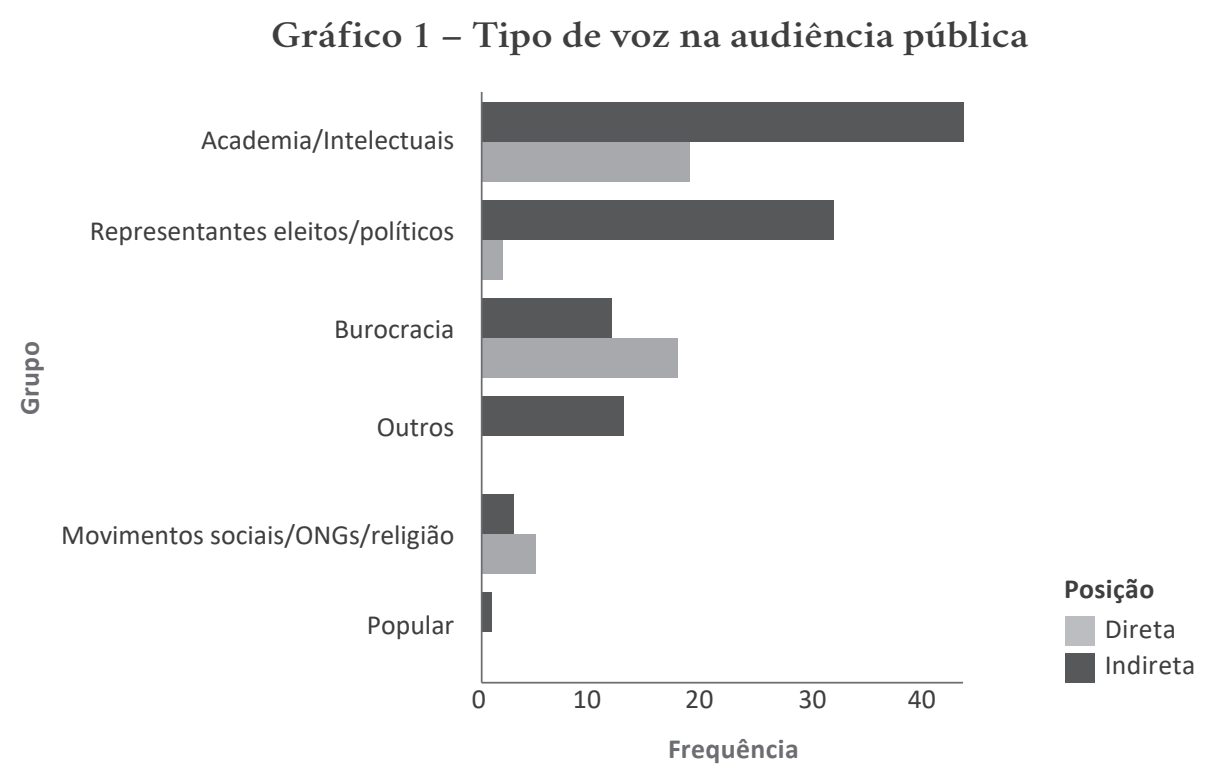

Fonte: Elaboração própria com base nas notas taquigráficas da audiência pública, disponibilizadas em: http:// www.stf.jus.br/arquivo/cms/processoAudienciaPublicaAcaoAfirmativa/anex o/Notas_Taquigraficas_Audiencia_ Publica.pdf.

\section{Gráfico 2 - Valência dos atores na audiência pública}

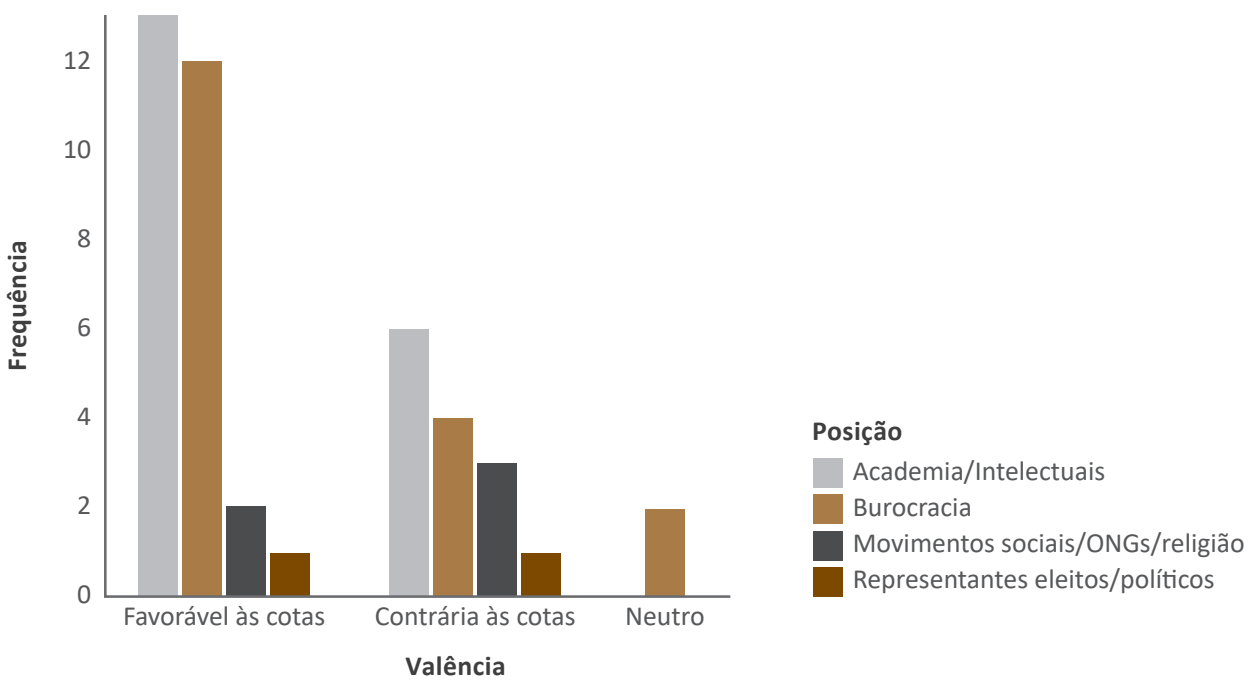

Fonte: Elaboração própria com base nas notas taquigráficas da audiência pública, disponibilizadas em: http:// www.stf.jus.br/arquivo/cms/processoAudienciaPublicaAcaoAfirmativa/anex o/Notas_Taquigraficas_Audiencia_ Publica.pdf. 
Chama atenção o fato de que entre o grupo de representantes de ONGs/ OSCs, teoricamente aqueles que falam pela sociedade civil, a posição majoritária, expressa pelos argumentos dos expositores, foi contrária à adoção da política de quotas. Isso pode ser reflexo do peso das organizações religiosas em detrimento da representação do movimento negro. Contudo, se a AP se propõe a operar como interface entre a sociedade civil e o Estado (MARONA; ROCHA, 2017), carece que seja mais plural a representação.

Entre os acadêmicos e intelectuais, argumentos favoráveis às quotas se destacaram. Esse padrão foi observado quando se trata do grupo de burocratas. A academia tem mobilizado importantes debates acerca de políticas afirmativas, articulando principalmente o referencial das teorias da justiça.

Nesse campo, os principais teóricos podem ser agrupados em tradições liberais ou comunitaristas, que correspondem a perspectivas procedimentais ou substanciais de justiça, respectivamente. Isto é, para os liberais, a justiça pode ser alcançada pela correção do procedimento, enquanto, para os comunitaristas, a justiça demanda construções substanciais, em termos de valores.

O que deu o título ao campo dos "comunitaristas" era principalmente a ideia dirigida contra Rawls de que é preciso sempre um retorno retrospectivo a um horizonte de valores comuns compartilhados, se se deve decidir com de modo razoável acerca de questões sobre a ordem justa da sociedade. O campo dos "liberais", por outro lado, foi nomeado ao contrário pela orientação comum à ideia central de Rawls de que sob condições modernas de um pluralismo de valores só o princípio geral da igualdade de direitos, liberdades e oportunidades pode servir como critério normativo pelo qual a justiça de uma comunidade deve ser medida (HONNETH, 1993 apud SIMIM, 2017, 391)

Retomaremos a este ponto adiante, quando analisarmos os argumentos mobilizados em apoio à política afirmativa de cunho étnico-racial na AP, na mídia e no acórdão.

Ainda sobre a pluralidade de vozes, é importante observar que, entre os expositores da AP, figuraram mais homens do que mulheres. Foram 32 homens e 12 mulheres. Já quando se considera o sexo daqueles que foram citados como fonte de autoridade argumentativa, homens constituem a maioria ainda mais expressiva: 87 homens e 17 mulheres. 


\section{Gráfico 3 - Sexo dos(as) participantes e citados(as) na audiência pública}

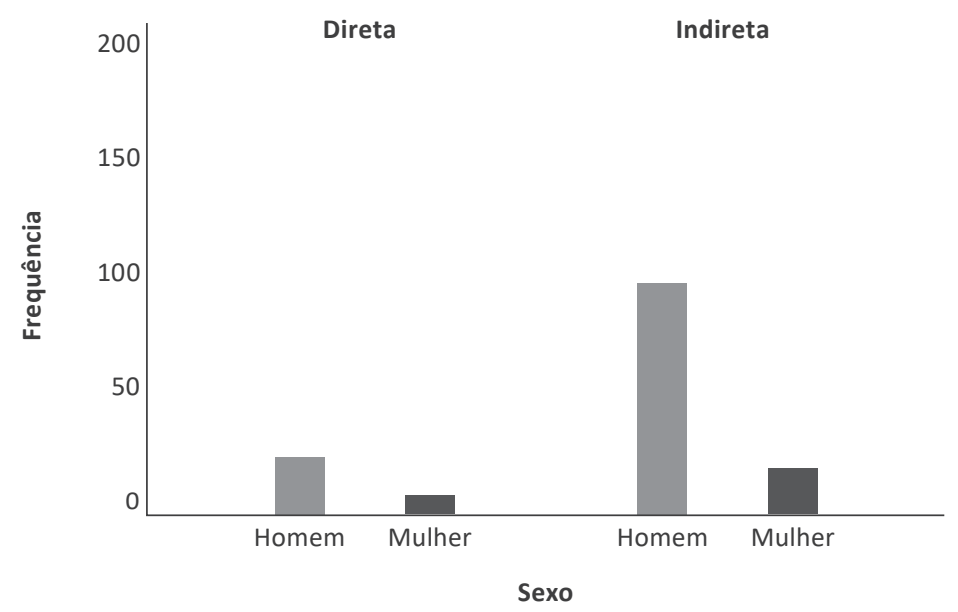

Fonte: Elaboração própria com base nas notas taquigráficas da audiência pública, disponibilizadas em: http://www.stf. jus.br/arquivo/cms/processoAudienciaPublicaAcaoAfirmativa/anexo/Notas_Taquigrafic as_Audiencia_Publica.pdf.

A inserção do STF no debate público, por meio da audiência pública, reproduz a desigualdade de gênero que marca outros ambientes públicos e as esferas decisórias e de poder, particularmente a academia, considerando que as vozes de intelectuais e acadêmicos foram as que ressonaram com maior força na audiência pública. Fiando-nos nas palavras de José Jorge de Carvalho, um dos palestrantes da "AP das Quotas", a desigualdade racial era ainda mais brutal.

Foram convocadas quarenta e três pessoas para estes três dias de audiência. Como se trata de discutir o ensino superior, é compreensível que o número de professores seja majoritário na composição dos palestrantes. Das quarenta e três pessoas convocadas a falar, trinta são professores - alguns evidentemente assumiram o cargo de administração do Estado e outros espaços especializados. O problema é que desses trinta professores, vinte e oito deles são brancos e apenas dois são negros: o Professor Kabengele Munanga e Mário Theodoro (JOSÉ JORGE DE CARVALHO, discurso proferido na AP e presente nas notas taquigráficas). 
Carvalho, então, propõe uma interpretação para tamanha desigualdade:

Ou seja, reproduzimos aqui, de um modo absolutamente não intencional, essa profunda segregação racial que é a marca do nosso sistema acadêmico. Temos aqui 93\% de professores brancos decidindo se devemos ou não consolidar ações afirmativas para negros nas universidades. Essa desproporção ou confinamento racial como costumo chamá-lo - já é em si mesma uma resposta possível à pergunta da audiência sobre a legitimidade e premência das cotas raciais. (JOSÉ JORGE DE CARVALHO, discurso proferido na AP e presente nas notas taquigráficas). Os textos de mídia, em seu conjunto, apresentam um perfil de vozes ativas bastante similar ao da audiência pública. As fontes acadêmicas são maioria na mídia, e funcionários do governo constituem a segunda fonte mais numerosa, em proporção ligeiramente inferior. O que se observa, contudo, é que, entre os acadêmicos, as opiniões aparecem bem mais equilibradas, em termos de valência. Por outro lado, a representação da sociedade civil (ONGs, MVs) aparece vinculada pela mídia a posicionamentos favoráveis à política de quotas. Como já apontado (DAFLON, FERES JÚNIOR, 2012; FERES JÚNIOR, CAMPOS, DAFLON, 2011), a forma como a mídia enquadra a questão descola da realidade a implementação da política, particularmente pelo recurso constante a generalizações de casos individuais, amiúde desviantes. 


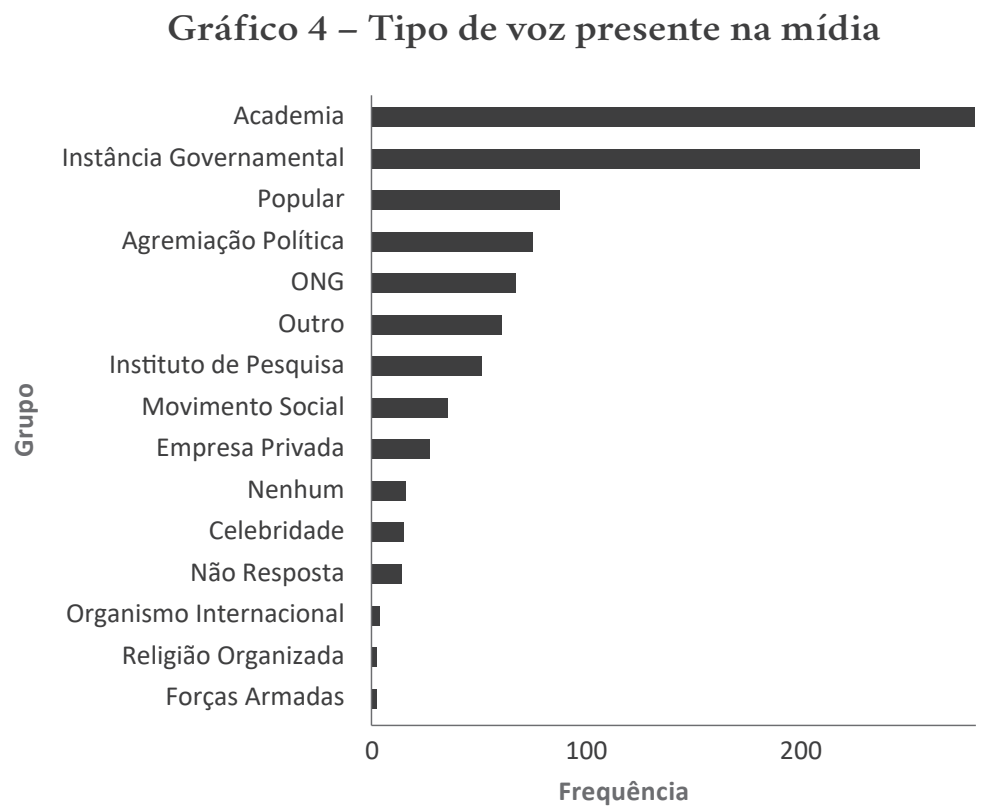

Fonte: Elaboração própria com base nos dados do GEMAA - Grupo de Estudos Multidisciplinar da Ação Afirmativa.

\section{Gráfico 5 - Valência dos atores na mídia}

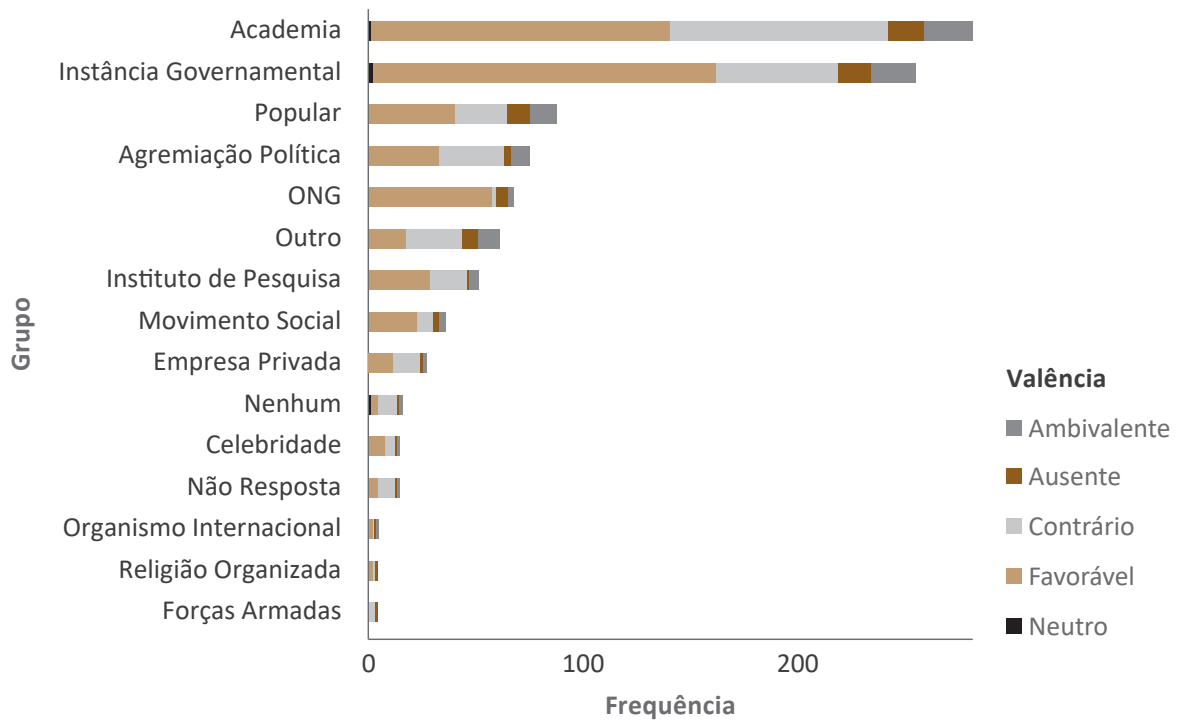

Fonte: Elaboração própria com base nos dados do GEMAA - Grupo de Estudos Multidisciplinar da Ação Afirmativa. 
Outra questão importante diz respeito ao fato de que a força das vozes de intelectuais e acadêmicos se reflete na construção dos argumentos presentes nos votos dos ministros do Supremo Tribunal Federal. Esse padrão indica que o STF privilegia o uso de opiniões de acadêmicos e intelectuais, como fonte de autoridade argumentativa, para justificar suas decisões.

A construção dos votos se dá tendo como base a argumentação científica, permeada por referências bibliográficas no campo das Ciências Sociais e do Direito, com produção acadêmica dos próprios ministros, inclusive.

\section{Gráfico 6 - Tipo de voz acionada no acórdão}

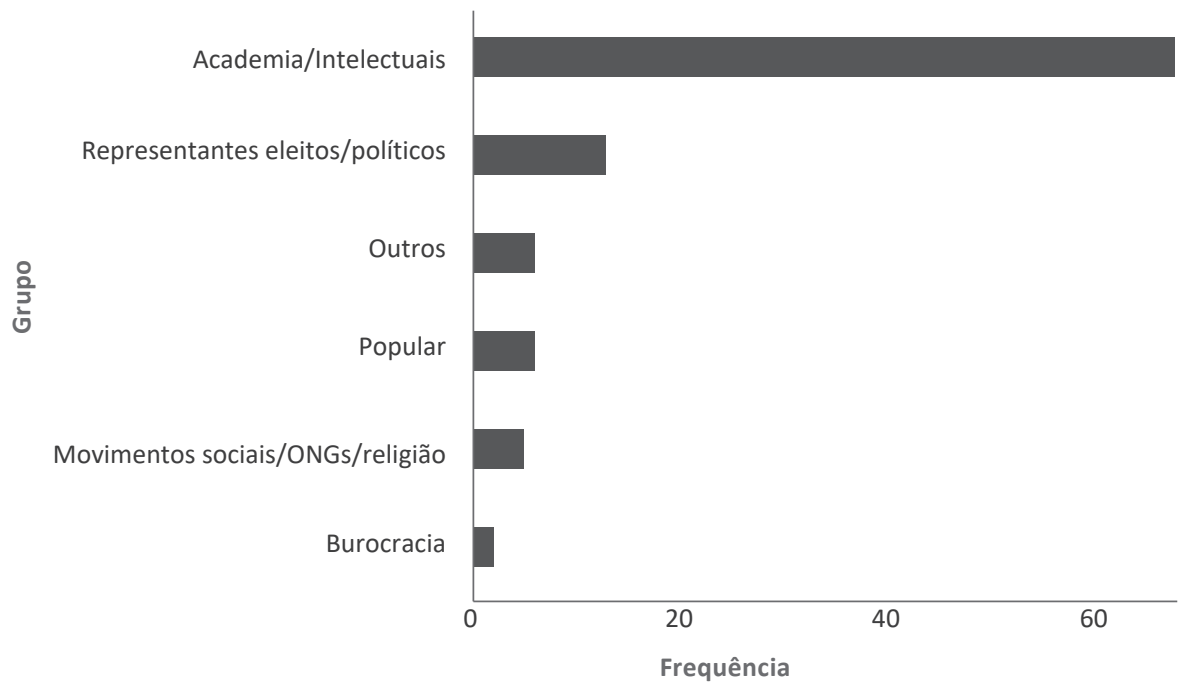

Fonte: Elaboração própria com base no acórdão, disponibilizado em: http://redir.stf.jus.br/paginadorpub/paginador. jsp?docTP=TP\&docID=6984693.

Interessante observar, portanto, do ponto de vista qualitativo, quais foram os principais argumentos representativos das posições contrárias e favoráveis à política de quotas. Neste ponto, destaca-se a diversidade argumentativa reverberada pela mídia na audiência pública e no acórdão (Anexo 1). Contudo, para fins de análise deste trabalho, os principais argumentos (favoráveis e contrários) foram agregados em categorias, o que permitiu a construção de um quadro analítico generalizável, extensivo a todos os documentos analisados.

No caso do grupo de argumentos contrários, optou-se por replicar, para fins comparativos, as categorias utilizadas anteriormente em análises qualitativas 
da cobertura midiática sobre a política afirmativa racial no ensino superior (FERES JÚNIOR, 2008). Nestes moldes, os argumentos contrários à ação afirmativa serão apresentados e classificados em três formações discursivas: "raça e identidade nacional", "cidadania e o Estado" e "procedimentos e resultados".

Os argumentos agrupados sob a formação discursiva "raça e identidade nacional" têm natureza sociológica e estão vinculados aos estudos sobre relações raciais, formando um discurso coerente que se aproxima da ideia de democracia racial, a qual funciona como uma barreira para a problematização do racismo, da discriminação racial e da desigualdade no espaço público.

O cerne da discussão passa pela ideia de que

os formuladores das políticas de ação afirmativa no Brasil importaram dos Estados Unidos um sistema binário de identificação racial que é completamente inadequado para entender a realidade da identidade racial e étnica do país, marcada pela plasticidade, flexibilidade e "contextualidade". Uma vez que a identidade nacional do Brasil fia-se em grande medida na ideia e nos valores de tolerância racial e miscigenação, a adoção desse sistema ameaça o núcleo da identidade e conduz ao conflito e à politização racial. (FERES JÚNIOR, 2008, p. 59-60)

Os argumentos agrupados sob a etiqueta "cidadania e Estado", por outro lado, são mais afetos à teoria política, moral e jurídica, aproximando-se da tradição liberal, seja em sua versão clássica, seja mobilizando uma de suas variações em defesa do Estado mínimo. Evocam os valores da igualdade formal e do mérito, condenando-se a intervenção do Estado nas relações sociais.

Em outras palavras, a forma com que o discurso é apresentado é altamente crítica ao Estado de bem-estar social. Nesse ponto, a crítica à ação afirmativa parece reconhecer, ainda que indiretamente, a estreita filiação entre ação afirmativa e Estado de bem-estar social, e que, portanto, a crítica da primeira poderia ser feita por meio da crítica radical do segundo. (FERES JÚNIOR, 2008, p. 67)

Por fim, os argumentos que se revelam de "procedimentos e resultados" estão unidos pela função retórica, expressa na afirmação da ineficiência da ação afirmativa ou na produção de efeitos indesejáveis. 
Os dados apontam para um padrão de discurso público contrário à política de quotas, que varia moderadamente quando se compara a cobertura realizada pela mídia com o que foi mobilizado pelos expositores na audiência pública e no acórdão pelos ministros do STF.

Gráfico 7 - Argumentos contrários por categoria: mídia, AP e acórdão (\%)

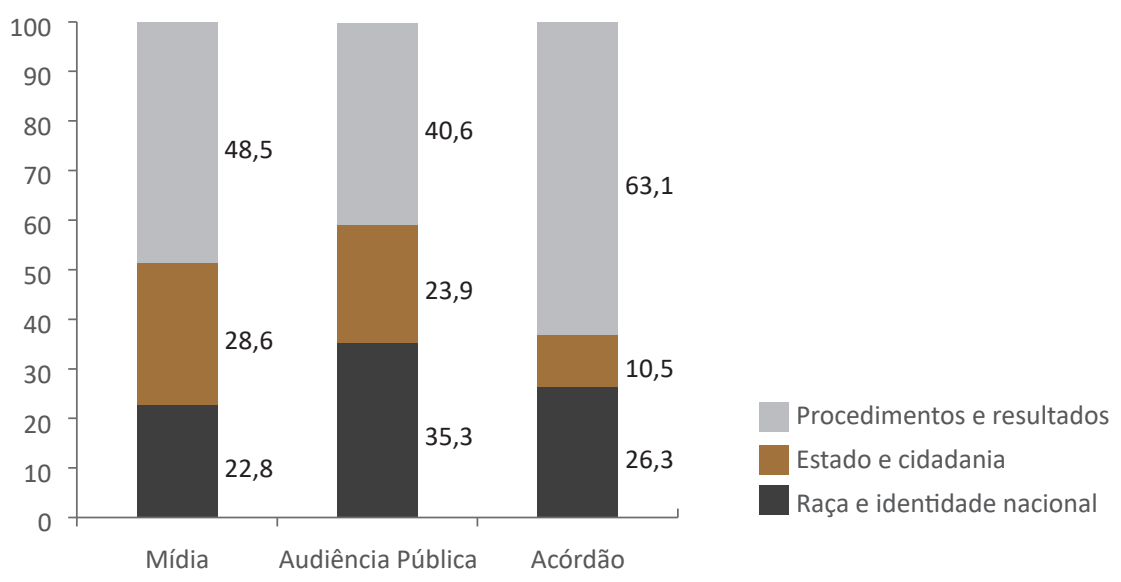

Fonte: Elaboração própria com base nos dados do GEMAA, nas notas taquigráficas da audiência pública e no acórdão, disponibilizados pelo STF.

Os discursos que envolvem argumentos instrumentais, vinculados ao debate acerca dos resultados da política afirmativa, são majoritariamente articulados, tanto na mídia $(48,5 \%)$ quanto na audiência pública $(40,6 \%)$ e, particularmente, no acórdão $(63,1 \%)$. Em relação à mídia, esses achados reforçam as conclusões de Daflon e Feres Junior. (2012) de que é o enquadramento da questão o instrumento de enviesamento do debate público. Isso porque, ao mobilizar a generalização de casos desviantes com o que se produz uma falsa representação da realidade de implementação da política de quotas, a mídia fomenta as discussões em torno dos procedimentos (classe ou raça?) e dos resultados (efetividade da política).

Por outro lado, a mobilização dessa categoria de argumentos na AP e, especialmente, no acórdão é indicadora de uma estratégia de construção decisória que evita a discussão substancial aventada pelas outras duas categorias (Estado e cidadania/Raça e identidade nacional) e que oporia, pelo menos virtualmente, a tradição liberal de justiça à comunitarista. Convém ressaltar 
que os argumentos de procedimento e resultado são de tipo instrumental, possibilitando a estratégia detectada.

Observe-se que, do ponto de vista mais substancial do debate, na audiência pública, os argumentos contrários mobilizados pelos expositores foram apoiados mais nas questões de "raça e da identidade nacional" do que de "Estado e cidadania”: $35,3 \%$ contra 23,9\%. Somada àquela informação e considerando a natureza dos argumentos agregados em cada uma das duas categorias - Estado e cidadania mais afetos à disciplina política e jurídica e raça e identidade nacional revelando debates de natureza sociológica acerca de relações sociais -, não deixa de ser interessante notar que a AP no STF funcionou como uma caixa de ressonância de um antigo e difundido debate, aquele sobre a democracia racial.

Ademais, considerando a dimensão temporal, é possível observar que, em 2010 (ano da realização da audiência pública) e, posteriormente, em 2012 (ano do julgamento da ação no STF), os argumentos contrários que veiculam o debate sobre raça e identidade nacional - os quais vinham perdendo projeção desde 2008 - não superam os outros dois grupos de argumentos em volume. Também do ponto de vista do volume, há uma clara regressão na mobilização de argumentos contrários à política de quotas raciais, a partir de 2008.

\section{Gráfico 8 - Argumentos contrários por categoria: evolução na cobertura midiática (2001-2012)}

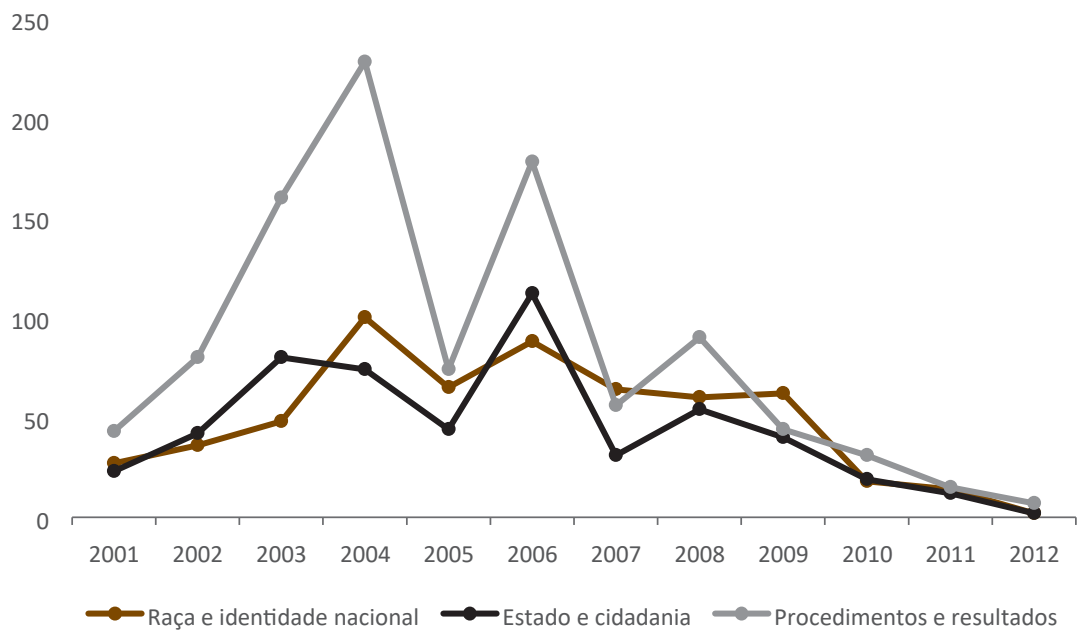


Convém analisar, por fim, o grupo de argumentos favoráveis, que deram suporte ao discurso público de apoio à política afirmativa de corte étnico-racial. Neste ponto, procedemos a seu agrupamento considerando outro conjunto de categorias, mais afetas à natureza do próprio discurso. Conforme já apontado (FERES JÚNIOR, 2008), três argumentos são usualmente mobilizados na justificação de ações afirmativas nos vários países em que essa modalidade de política pública é empregada: reparação, justiça social e diversidade. De uma maneira geral, os três "tipos de argumentos" de justificação têm a mesma finalidade, que é indicar a adequação da política aos imperativos da justiça social. Entretanto, existem diferenças teóricas relevantes, no que diz respeito ao modo como esses conjuntos de argumentos são construídos, que justificam sua classificação.

Tomando, portanto, como ponto de partida o reconhecimento da relação entre a teoria política e moral do liberalismo igualitário e a justificação de políticas de ação afirmativa de corte étnico-racial, os argumentos favoráveis às quotas raciais mobilizados na cobertura midiática, na audiência pública e no acórdão foram classificados nas seguintes categorias:

(i) reparação, os que sugerem que as iniciativas visam restituir ou mitigar perdas provenientes de injúria ou crime do passado - a escravidão é o exemplo mais claro e também mais significativo, (ii) justiça social que apontam para o fato de que qualquer desigualdade injustificada constitui de fato uma injustiça que potencialmente deve ser de alguma maneira mitigada por ação estatal; (iii) diversidade, em grande medida baseado na expediência, ou seja, no suposto ganho de qualidade de ensino e de serviço que um corpo estudantil formado por pessoas de diversas origens sociais e culturais proporcionaria. (FERES JÚNIOR; CAMPOS, 2013, p. 86-87)

O gráfico 9 apresenta os dados referentes aos argumentos favoráveis, mobilizados no debate público. A variação aqui é ainda mais sútil do ponto de vista do padrão de articulação das três categorias de argumentos: o posicionamento favorável à política de quotas de corte étnico-racial se justificou massivamente sob argumentos de justiça social. 


\section{Gráfico 9 - Argumentos favoráveis por categoria: mídia, AP e acórdão}

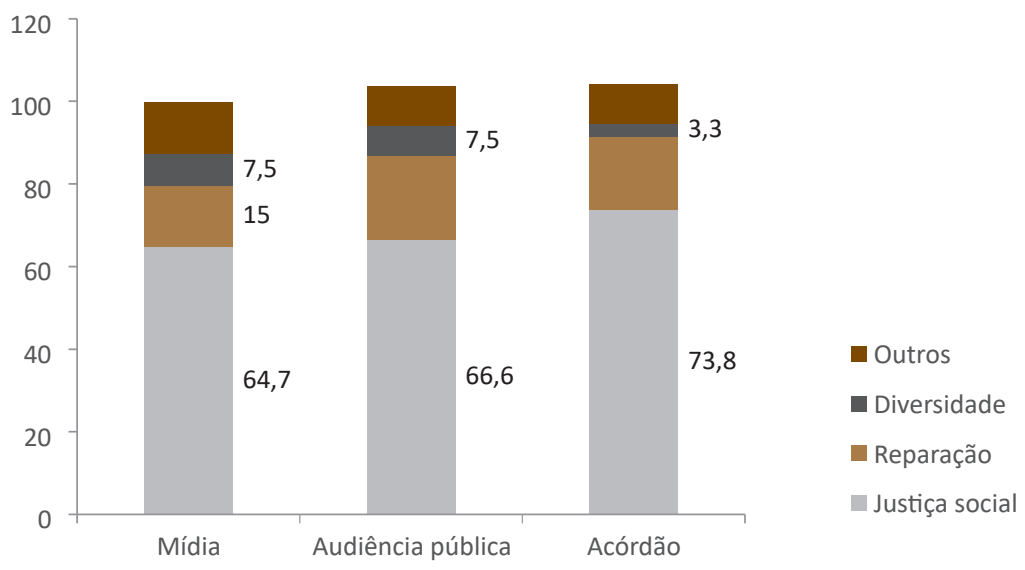

Fonte: Elaboração própria com base nos dados do GEMAA, nas notas taquigráficas da audiência pública e no acórdão, disponibilizados pelo STF.

A mobilização do argumento de justiça social remete à ideia central de que o conjunto de desigualdades que caracteriza a sociedade brasileira, seja fruto de discriminação/preconceito, seja por oportunidades de acesso a bens públicos muito díspares, deve ser objeto de políticas públicas.

Trata-se de um argumento tipicamente liberal, em sua vertente igualitária (RAWLS, 1971), que desconsidera a causa da desigualdade, dando relevo à obrigação do Estado de atuar no sentido da extinção da desigualdade. Opõe-se, no campo da teoria, àquele conjunto de argumentos articulados pela tradição comunitarista, representados aqui pelos argumentos de reparação.

Os comunitaristas se opõem às teses procedimentalistas de justiça, fazendo-a derivar, teoricamente, de um conjunto substantivo de valores, que é particular a cada sociedade e está inscrito em suas instituições (MACINTYRE, 1981; SANDEL, 1982; TAYLOR, 1984; WALZER, 1983). Aquele conjunto de valores seria a base de uma identidade coletiva comum, cujo processo de negociação pública ocorreria pelo exercício da razão pública via argumentos necessariamente históricos e interpretativos.

Assim, argumentos que visem a reformular o conjunto básico de valores e as instituições que deles derivam devem recorrer à interpretação da história coletiva comum. Justamente nesse ponto a tradição comunitarista toca aos 
argumentos de reparação, conforme aqui classificados. Argumentos de reparação apontam para a necessidade de restituição ou mitigação de perdas provenientes de injúrias ou crimes históricos - a escravidão é, nesse quadro discursivo, o fato histórico mobilizado por excelência. Mas, retomar o fato histórico da escravidão como um mote para a obrigatória reparação pública a negras e negros tensiona o discurso da democracia racial, que tem funcionado como uma barreira para a problematização do racismo estrutural da sociedade brasileira.

Não por acaso, conforme apontado, quando se enquadra o debate público em termos de justiça (liberais versus comunitaristas), aqueles que, na audiência pública, se posicionaram de forma contrária à política de quotas preferiram argumentos de "raça e identidade nacional" aos de "Estado e cidadania", em reforço ao mito da democracia racial.

É interessante notar, ainda, que o debate público presente na mídia e aquele abordado nas audiências públicas e no acórdão seguem um padrão semelhante. Uma das razões para isso pode ser pelas vozes ouvidas. Como vimos inicialmente, os principais atores ouvidos pela mídia e em evidência na AP são aqueles que representam a academia - seja para argumentos contrários ou favoráveis. Quando observamos quem são essas pessoas na mídia e nas APs, veremos que são as mesmas. Ou seja, os argumentos que perpassaram as duas arenas são muito próximos, resguardadas as diferenças decorrentes das especificidades de cada instituição.

Apesar da semelhança qualitativa nos argumentos apresentados na mídia, nas audiências públicas e no acórdão, é preciso observar o diferencial quantitativo, conforme apontam os quadros no Anexo 1. Neles é possível ver que a AP foi a arena que apresentou maior desenvolvimento de justificações favoráveis às quotas raciais. E esse apelo pela inclusão de vozes/argumentos em favor das quotas é expresso na fala de Sueli Carneiro:

Senhor Ministro, como todos os que me antecederam, ressalto inicialmente a importância de sua iniciativa de convocação dessa audiência pública que está permitindo que a pluralidade de vozes que se posicionam a favor da política de quotas para negros no ensino superior possam ser ouvidas por esta Corte e pelo conjunto da sociedade. Sabemos perfeitamente que essa diversidade de apoios de que gozam as quotas para negros não está democraticamente presente no debate público sobre o tema, o que torna a sua iniciativa ainda mais relevante. 


\section{Conclusão}

Das inúmeras inovações institucionais que acompanharam o aprofundamento do protagonismo do Supremo Tribunal Federal nas últimas décadas no Brasil, as audiências públicas merecem destaque. Se não pelo potencial inclusivo, em atenção aos reclames de maior controle direto da soberania sobre a Corte, pela virtual capacidade de alterar a posição do STF no debate público, considerando a pluralidade de vozes e argumentos que mobiliza.

A audiência pública realizada no STF por ocasião do julgamento da ADPF 186, que veiculava pretensão do DEM de declarar inconstitucional a política afirmativa de corte étnico-racial que vinha sendo introduzida no País, se revelou uma oportunidade para testar aquela capacidade.

Desde 2002, o tema da ação afirmativa na sociedade brasileira havia sido colocado na pauta do debate público. A mídia vinha realizando intensa cobertura, como a principal responsável pela condução do debate público sobre as quotas raciais, em decorrência do papel fundamental que exerce em sociedades de massa - circulação de informações e opiniões - na construção de uma visão de mundo complexa e em constante atualização.

Evitando a identificação entre o conjunto de opiniões expressas na mídia e a opinião pública, pela consideração do lugar central que ocupa a concepção de "público" em democracias, é preciso reconhecer que os meios de comunicação detêm o poder de agenda setting e de conformarem (frame) os vários assuntos dessa agenda (BERGER; LUCKMANN, 1990; GITLIN, 2003).

Esse é o caso do debate público em torno das quotas raciais: apesar do volume de textos contrários à política afirmativa de corte étnico-racial, as pesquisas de opinião pública sobre o tema revelavam apoio de parcela significativa da população. Ademais, o Supremo Tribunal Federal decidiu, de forma unânime, pela constitucionalidade da política. No âmbito desse processo realizou a "AP das quotas", que reuniu atores de diversos setores da sociedade e do governo, com destaque para a centralidade que intelectuais e acadêmicos alcançaram.

Não se pode dizer que foi a AP que alçou o grupo de intelectuais e acadêmicos, considerando que a "voz da academia" ecoava na mídia de modo preferencial, em relação a outros grupos de atores ligados ao governo ou mesmo ligados a MVs e OSCs. A diferença nesse ponto é que, na AP, a “academia” mobilizou 
majoritariamente argumentos favoráveis às quotas, enquanto, na mídia, a distribuição entre argumentos pros e contras foi mais equilibrada. Ademais, a AP reproduziu as desigualdades de gênero e raça visualizadas em outros espaços públicos, particularmente na "academia”.

Outro achado interessante diz com o fato de que, enquanto os representantes da sociedade civil mobilizaram massivamente argumentos contrários às quotas na AP - muito provavelmente pela distorção representativa causada pela presença de grupos religiosos -, na mídia, essas "vozes” foram associadas a argumentos favoráveis. Esse pode ser um elemento da estratégia midiática de introduzir viés negativo sobre as quotas no debate público. A vinculação massiva de argumentos favoráveis às quotas a MVs e OSCs visa a politizar o debate que, por outro lado, é enquadrado a partir de seu descolamento da realidade de implementação da política, por meio de generalizações de casos de distorções pontuais.

O acórdão do STF, favorável à política de quotas, reverberou a hegemonia da academia como fonte de justificativa, com recurso a argumentos instrumentais (de procedimento e resultado). Argumentos dessa natureza foram, aliás, os mais mobilizados também na AP e pela mídia. Por um lado, os achados reforçam as conclusões de Daflon e Feres Junior (2012) de que é o enquadramento da questão o instrumento de enviesamento do debate público por parte da mídia, pela manipulação de técnicas de generalização de casos desviantes.

Produz-se uma falsa representação da realidade fomentando as discussões em torno dos procedimentos (classe ou raça?) e dos resultados (efetividade da política). Ademais, a opção pela mobilização de argumentos instrumentais, tanto na AP quanto no acórdão, indica uma estratégia de construção decisória que evita a discussão substancial que as categorias identificadas como "Estado e cidadania" e "Raça e identidade nacional" impunham. Consequentemente, não se avança o debate acerca da adequação constitucional das distintas concepções de justiça (AVRITZER, MARONA, 2014) que as tradições liberal e comunitarista oferecem como anteparo à política afirmativa de recorte racial. Sobre essa questão convém destacar a vinculação entre os argumentos contrários e a tradição comunitarista de justiça, com recurso a argumentos de raça e identidade racial, que reforça o mito da democracia racial brasileira. Entre os argumentos favoráveis, por outro lado, mobilizados tanto pela mídia quanto na AP e reproduzidos no acórdão, os que clamam por "reparação" - aproximados aos contrários de "raça e identidade nacional” - não são os mais mobilizados. 
Ao contrário recorre-se majoritariamente aos argumentos alinhados à tradição liberal, na sua versão igualitária - aqueles que clamam por justiça social e colocam em relevo a obrigação do Estado de atuar contra qualquer tipo de desigualdade, sem levar em consideração a sua causa. De um modo geral, pode-se dizer que os resultados reforçam o viés de cobertura da mídia brasileira, já identificado em trabalhos anteriores, mas não confirmam o potencial das APs de promover inclusão (de vozes e argumentos) ao debate público.

\section{Referências}

ARIEDE, Elouise Bueno. Audiências públicas no Supremo Tribunal Federal: um estudo comparativo de sua prática, antes e após o advento da Emenda Regimental n²9, de 2009. 80 f. Monografia. São Paulo: Sociedade Brasileira de Direito Público, Escola de Formação, 2011. Disponível em: https://sbdp.org.br/ wp/wp-content/uploads/2018/04/188_Elouise-Bueno-Ariede.pdf. Acesso em: 10 set. 2021.

AVRITZER, Leonardo; MARONA, Marjorie Corrêa. Judicialização da política no Brasil: ver além do constitucionalismo liberal para ver melhor. Revista Brasileira de Ciência Política, v. 1, n. 15, p. 69-94, set./dez. 2014. Disponível em: https:// www.scielo.br/j/rbcpol/a/nVfCQd8qFdNGB6KDJpbYdFp/?lang=pt\&format=pdf. Acesso em: 10 set. 2021.

BARBOSA, Claudia Maria; PAMPLONA, Danielle Anne. A judicialização da política e as audiências públicas no Supremo Tribunal Federal. Revista Paradigma, n. 18, jul./dez. 2009. Disponível em: https://revistas.unaerp.br/ paradigma/article/view/43. Acesso em: 10 set. 2021.

BARROSO, Luís Roberto. A razão sem voto: o Supremo Tribunal Federal e o governo da maioria. Revista Brasileira de Políticas Públicas, v. 5, 2015, p. 23-50. Número especial.

BATEUP, Christine. A. The dialogic promise: assessing the normative potential of theories of Constitutional dialogue. Brooklyn Law Review, v. 71, n. 3, p.1109-1180, 2006. Disponível em: https://brooklynworks.brooklaw.edu/cgi/ viewcontent.cgi? article $=1378 \&$ context $=$ blr. Acesso em: 12 set. 2021 . 
BENEDETTI, Miguel Ángel; SÁENZ, María Jimena. Las audiencias públicas de la Corte Suprema: apertura y límites de la participación ciudadana en la Justicia. Buenos Aires: Siglo XXI Editores, 2016. 288p. Disponível em: https://www. researchgate.net/profile/Maria-Saenz-6/publication/343750205_Benedetti_y_ Saenz_-_Las_audiencias_publicas_de_la_Corte_Suprema_Apertura_y_ limites_de_la_participacion_ciudadana_en_la_justicia-Siglo_Veintiuno_2016/ links/5f3db068a6fdcccc43d63c31/Benedetti-y-Saenz-Las-audiencias-publicasde-la-Corte-Suprema-Apertura-y-limites-de-la-participacion-ciudadana-en-lajusticia-Siglo-Veintiuno-2016.pdf. Acesso em: 13 set. 2021.

BERGER, Peter L.; LUCKMAN, Thomas. Social construction of reality: treatise on the Sociology of Knowledge. Harmondswirth: Penguin Books, 1990.

BICKEL, Alexander M. The least dangerous branch: the Supreme Court at the bar of politics. New Haven, Connecticut, EUA: Yale University Press, 1986.

CAMPOS, Luiz Augusto; FERES JÚNIOR, João. O Globo e as ações afirmativas: dez anos de cobertura (2001-2011). Rio de Janeiro: IESP; UERJ, 2013. 18p. (Textos para discussão GEMAA (IESP-UERJ), n. 2). Disponível em: http://gemaa.iesp. uerj.br/wp-content/uploads/2018/03/TpD-gemaa-2.pdf. Acesso em: 13 set. 2021.

CHARMAZ, Kathy. Constructionism and the grounded theory method. In: HOLSTEIN, J. A.; GUBRIUN, J. F. (ed.). Handbook of Constructionist Research, 2008. v. 1, p. 397-412. Disponível em: http://www.sxf.uevora.pt/ wp-content/uploads/2013/03/Charmaz_2008-a.pdf. Acesso em: 13 set. 2021.

DAFLON, Veronica Toste; FERES JÚNIOR, João. Ação afirmativa na revista Veja: estratégias editoriais e o enquadramento do debate público. Revista Compolítica, v. 2, n. 2, p.66-91, jul./dez. 2012

DWORKIN, Ronald. Uma questão de princípio. São Paulo: Martins Fontes, 2001.

DWORKIN, Ronald. O império do Direito. São Paulo: Martins Fontes, 2007.

DWORKIN, Ronald. Levando os direitos a sério. São Paulo: Martins Fontes, 2010. 
FEREJOHN, John; PASQUINO, Pasquale. Constitutional courts as deliberative institutions: towards an institutional theory of constitutional justice. In: SADURSKI, Wojciech (ed.). Constitutional justice, East and West: democratic legitimacy and Constitutional Courts in Post-Communist Europe in a comparative perspective. Great Britain: Kluwer Law International, 2002. p. 21-36. (Law and Philosophy library, 62). Disponível em: https://d1wqtxts1xzle7. cloudfront.net/47298268/Constitutional_Courts_as_Deliberative_In2016071732684-11 mjcgq-with-cover-page-v2.pdf?Expires $=1631558331 \&$ Signature $=M$ 6LUt5PTOENH3 GNDVFI4-sH1OGO 8j8oo7DpJNAM9z1kC4PkxeKDo 5Dc-viVtMjM $\sim$ Y5BoLwS4U1ZeXoMq1rMQ7OwZGeb7KTMr9YrH6tH8tnK I3LMR5tSBfTHT KpW9LTpfWQ76y-HBEU57bo2fSenVVWJy22jSjBk0PruK 1BC7rMOctsGjT94yygFTvB5M55oOgypq3LA0am-ZtnSjY7-ANGRmloy9D NUMqGE1fXEdfmYDAUxysGP18pmx9Sxc96xTR7i4Q7ybn26kaCn6Zd3nY NYrCIM5vVx4s68VdKQq1xxjgieHd H4tTTaaKWPzx1IQKcey2tXCmQPU6U 〜Uqg_\&Key-Pair-Id=APKAJLOHF5GGSLRBV4ZA. Acesso em: 13 set. 2021.

FEREJOHN, John; PASQUINO, Pasquale. Rule of democracy and rule of law. In: MARAVALL, J.; PRZEWORSKI, A. (ed.). Democracy and the rule of Law. Cambridge: Cambridge University Press, 2003. p. 242-260. (Cambridge studies in the theory of democracy, v. 5). Doi:10.1017/CBO9780511610066.

FERES JÚNIOR, João. Ação afirmativa: política pública e opinião. Sinais Sociais, v. 3, n. 8, p. 38-77, 2008. Disponível em: http://flacso.redelivre.org.br/ files/2012/07/641.pdf. Acesso em: 13 set. 2021.

FERES JÚNIOR, João. Ação afirmativa no Brasil: a política pública entre os movimentos sociais e a opinião douta. In: SILVÉRIO, Valter Roberto; MOEHLECKE, Sabrina (ed.). Ações afirmativas nas políticas educacionais: o contexto pós-Durban. São Carlos: EdUFSCar, 2010. p. 35-51.

FERES JÚNIOR, João; CAMPOS, Luiz Augusto. Liberalismo igualitário e ação afirmativa: da teoria moral à política pública. Revista de Sociologia e Política, v. 21, n. 48, p. 85-99, dez. 2013. Disponível em: https://www.scielo. $\mathrm{br} / \mathrm{j} / \mathrm{rsocp} / \mathrm{a} / \mathrm{WwXcCycCTzDB} 6 \mathrm{KwWdPTWLBb} /$ ?format=pdf\&lang=pt. Acesso em: 13 set. 2021.

FERES JÚNIOR, João; CAMPOS, Luiz Augusto; DAFLON, Veronica Toste. Fora de quadro: a ação afirmativa nas páginas d'O Globo. ContemporâneaRevista de Sociologia da UFSCar, v. 1, n. 2, p. 61-83, jul./dez. 2011. Disponível em: https://www.contemporanea.ufscar.br/index.php/contemporanea/article/ view/37/19. Acesso em: 13 set. 2021. 
FERES JÚNIOR, João; DAFLON, Veronica Toste; CAMPOS, Luiz Augusto. Cotas no STF: os argumentos como eles são. Insight Inteligência, v. 12, n. 49, p. 124-136, abr./jun. 2010. Disponível em: https://inteligencia.insightnet.com. br/pdfs/49.pdf. Acesso em: 13 set. 2021.

FRAGALE FILHO, Roberto. Audiências públicas e seu impacto no processo decisório: a ADPF 54 como estudo de caso. Revista Direito e Práxis, v. 6, n. 3, p. 504-535, 2015. Disponível em: https://www.e-publicacoes.uerj.br/index.php/ revistaceaju/article/view/19230/14049. Acesso em: 13 set. 2021.

FRIEDMAN, Barry. The will of the people: how public opinion has influenced the Supreme Court and shaped the meaning of the Constitution. New York: Farrar, Straus and Giroux, 2009.

GITLIN, Todd. The whole world is watching: mass media in the making and unmaking of the new left. Berkeley: Univ of California Press, 2003. 352p.

HÄBERLE, Peter. El estado constitucional. México: Universidad Nacional Autónoma de México, 2003. Disponível em: https://biblio.juridicas.unam.mx/ bjv/detalle-libro/14-el-estado-constitucional-1a-reimp. Acesso em: 13 set. 2021.

HIRSCHL, Ran. Towards juristocracy: the origins and consequences of the new constitutionalism. Cambridge: Harvard University Press, 2009.

ISUNZA, Ernesto; DE LA JARA, Felipe Hevia. Relaciones sociedad civil-estado en México: um ensayo de interpretación. México: Centro de Investigaciones y Estudios Superiores en Antropología Social; Instituto de Investigaciones Histórico-Sociales/Universidad Veracruzana, 2006. 133 p. Disponível em: https://fundacionmerced.org/bibliotecadigital/wp-content/uploads/2021/01/1_ Relaciones_sociedad_civil-Estado_en_Mexi.pdf. Acesso em: 13 set. 2021.

LAVILLE, Christian; DIONNE, Jean. A construção do saber: manual de metodologia da pesquisa em ciências humanas. Porto Alegre: Artmed, 1999. 340p.

LEITE, Carina L. S. As audiências públicas no STF: mero instrumento de legitimação formal? In: SARMENTO, Daniel (coord.). Jurisdição constitucional e política. Rio de Janeiro: Editora Forense, 2015. p. 489-526. 
LIMA, Rafael Scavone Bellem de. A audiência pública realizada na ADI 3510-0: a organização e o aproveitamento da primeira audiência pública da história do Supremo Tribunal Federal. 2008. 79 f. Monografia. São Paulo: Sociedade Brasileira de Direito Público, Escola de Formação. Disponível em: https://sbdp. org.br/wp/wp-content/uploads/2018/02/125_rafael.pdf. Acesso em: 13 set. 2021.

MACINTYRE, Alasdair C. After virtue: a study in moral theory. Notre Dame: University of Notre Dame Press, 1981. ix, 252 p.

MARONA, Marjorie Corrêa; ROCHA, Marta Mendes. As audiências públicas do Supremo Tribunal Federal: ampliando sua legitimidade democrática? Teoria \& Sociedade (UFMG), n. 22.1, p. 53-86, jan./jun. 2014. Disponível em: https:// www.researchgate.net/publication/331314449_As_Audiencias_Publicas_do_ Supremo_Tribunal_Federal_ampliando_a_legitimidade_democratica. Acesso em: 13 set. 2021.

MARONA, Marjorie Corrêa; ROCHA, Marta Mendes da. Democratizar a jurisdição constitucional?: o caso das audiências públicas no Supremo Tribunal Federal. Revista de Sociologia e Política, v. 25, n. 62, p. 131-156, jun. 2017. Disponível em: https://revistas.ufpr.br/rsp/article/view/53764/32850. Acesso em: 13 set. 2021.

MEDINA, José Miguel Garcia; FREIRE, Alexandre; FREIRE, Alonso. Audiência pública tornou-se instrumento de legitimidade. Consultor Jurídico, 4 jul. 2013. Disponível em: https://www.conjur.com.br/2013-jul-04/audiencias-publicastornaram-stf-instrumento-legitimidade-popular. Acesso em: 13 set. 2021.

MENDES, Conrado Hübner. Not the last word, but dialogue: deliberative separation of powers 2. Legisprudence, v. 3, n. 2, p. 191-246, 2009. Disponível em: https://papers.ssrn.com/sol3/papers.cfm?abstract_id=1911835. Acesso em: 13 set. 2021.

NOTAS TAQUIGRÁFICAS DA AUDIÊNCIA PÚBLICA SOBRE ACÃO AFIRMATIVA STF. Disponível em: https://redir.stf.jus.br/paginadorpub/ paginador.jsp?docTP=TP\&docID=6984693. Acesso em: 28 set. 2021 .

PESSOA, Lia Braga. O STF como ator de mudanças sociais relevantes: uma análise da ADPF 54. 2012. 100 f. Monografia. São Paulo: Sociedade Brasileira de Direito Público, Escola de Formação. Disponível em: https://sbdp.org.br/wp/ wp-content/uploads/2018/04/208_Lia-Braga-Pessoa.pdf. Acesso em: 13 set. 2021. 
PIRES, Roberto R. C.; VAZ, Alexander C. N. Participação social como método de governo?: um mapeamento das" interfaces socioestatais" nos programas federais. Rio de Janeiro: IPEA, 2012. 56 p. (Textos para discussão, 1707) Disponível em: https://www.ipea.gov.br/portal/images/stories/PDFs/TDs/td_1707.pdf. Acesso em: 13 set. 2021 .

PIRES, Roberto R. C.; VAZ, Alexander C. N. Para além da participação: interfaces socioestatais no governo federal. Lua Nova, n. 93, p. 61-91, 2014. Disponível em: https://doi.org/10.1590/S0102-64452014000300004. Acesso em: 13 set. 2021.

RAWLS, John. A theory of justice. Cambridge, Mass.: Belknap Press, 1971. $\mathrm{xv}, 607 \mathrm{p}$.

SANDEL, Michael J. Liberalism and the limits of justice. Cambridge, UK: Cambridge University Press, 1982. ix, 191 p.

SILVA, Cecília de Almeida; AJOUZ, Igor. Audiências públicas na Suprema Corte Brasileira: novas tendências para o diálogo social. Revista da AGU, v. 12, n. 37, p. 129-160, jul./set. 2013. Disponível em: https://seer.agu.gov.br/index.php/ AGU/article/view/35/33. Acesso em: 7 set. 2021.

SIMIM, Thiago Aguiar. Entre comunitaristas e liberais: a teoria da justiça de Axel Honneth. Revista Direito e Práxis, v. 8, n. 1, p. 386-412, mar. 2017. Disponível em: https://doi.org/10.12957/dep.2017.21886. Acesso em: 1 set. 2021.

SOMBRA, Thiago Luís Santos. Supremo Tribunal Federal representativo?: o impacto das audiências públicas na deliberação. Revista Direito GV, v. 13, n. 1, p. 236-273, jan./abr. 2017. Disponível em: https://bdjur.stj.jus.br/jspui/ bitstream/2011/110833/supremo_tribunal_federal_sombra.pdf. Acesso em: 13 set. 2021.

TAYLOR, Charles. Hegel: history and politics. In: SANDEL, M. (ed.). Liberalism and its critics. New York: New York University Press, 1984. p. 177-199.

TULIS, Jeffrey K. Deliberation between institutions. In: FISHKIN, James S.; LASLETT, Peter (ed.). Debating deliberative democracy. Hoboken, Nova Jersey, EUA: Blackwell Publishing Ltd, 2003. p. 200-211.

VESTENA, Carolina. "Audiências públicas: diagnóstico empírico sobre os limites da participação social”, Revista Brasileira de Estudos Constitucionais, v. 6, n. 24, p. 973-1020, out./dez. 2012. 
VIEIRA, Oscar Vilhena. Supremocracia. Revista Direito GV, v. 4, n. 2, p. 441-63, dez. 2008. Disponível em: https://doi.org/10.1590/S1808-24322008000200005. Acesso em: 13 set. 2021.

WALZER, Michael. Spheres of justice: a defense of pluralism and equality New York: Basic Books, 1983. xviii, 345 p.

WOOLMAN, Stu; BISHOP, Michael. Constitutional conversations. Pretoria: Pretoria University Law Press, 2008. 


\section{ANEXO 1}

Argumentos contrários e favoráveis (desagregados) mobilizados pela mídia, na audiência pública e no acórdão.

Quadro 1: Justificações contrárias

\begin{tabular}{l|c|c|c}
\hline & Mídia & $\begin{array}{c}\text { Audiência } \\
\text { Pública }\end{array}$ & Acórdão \\
\hline O caminho é investir no ensino básico & 43 & 16 & 1 \\
\hline AAR é discriminação às avessas & 37 & 11 & 2 \\
\hline AAR é inconstitucional/ilegal & 31 & 12 & 0 \\
\hline AAR não leva em conta o mérito & 30 & 9 & 0 \\
\hline Classe importa mais que raça & 24 & 10 & 4 \\
\hline AAR não basta sem medidas para a permanên- \\
cia dos beneficiários & 24 & 2 & 3 \\
\hline AAR diminui a qualidade do ensino & 22 & 0 & 0 \\
\hline AAR pode estigmatizar os beneficiários & 19 & 7 & 0 \\
\hline AAR é ineficiente no combate às desigualdades & 17 & 7 & 0 \\
\hline O caminho é investir nas políticas universais & 17 & 3 & 1 \\
\hline AAR pode impor uma identidade bicolor & 17 & 8 & 0 \\
\hline $\begin{array}{l}\text { AAR viola o princípio da igualdade formal/ins- } \\
\text { titui privilégios }\end{array}$ & 16 & 3 & 0 \\
\hline É difícil classificar racialmente as pessoas & 16 & 19 & 0 \\
\hline AAR oficializa o racismo & 15 & 7 & 0 \\
\hline AAR cria/acirra conflito racial & 13 & 14 & 1 \\
\hline AAR importa um modelo estrangeiro & 13 & 7 & 0 \\
\hline AAR racializa a sociedade & 12 & 8 & 0 \\
\hline AAR é solução paliativa & 11 & 3 & 0 \\
\hline AAR pode excluir os brancos pobres & 10 & 6 & 2 \\
\hline AAR pressupõe a existência biológica de raças & 10 & 9 & 0 \\
\hline Beneficiários não serão capazes de acompanhar & 9 & 0 & 0 \\
\hline
\end{tabular}




\begin{tabular}{|c|c|c|c|}
\hline & Mídia & $\begin{array}{c}\text { Audiência } \\
\text { Pública }\end{array}$ & Acórdão \\
\hline AAR tende a beneficiar classe média/elite negra & 7 & 4 & 3 \\
\hline AAR é vulnerável à fraude & 7 & 5 & 0 \\
\hline AAR se opõe à nossa tradição de mestiçagem & 6 & 7 & 0 \\
\hline O ensino já está se democratizando sem quotas & 5 & 1 & 0 \\
\hline AAR é uma medida eleitoreira & 4 & 0 & 0 \\
\hline AAR não deve ser reduzida às quotas & 4 & 1 & 0 \\
\hline AAR pode dividir classes baixas & 4 & 2 & 0 \\
\hline AAR pode excluir grupos discriminados & 3 & 7 & 0 \\
\hline $\begin{array}{l}\text { AAR é intervenção do Estado nas relações } \\
\text { sociais }\end{array}$ & 2 & 4 & 0 \\
\hline AAR desrespeita a autoidentificação & 2 & 11 & 0 \\
\hline AAR cria intolerância entre os negros & 2 & 3 & 0 \\
\hline AAR produzirá profissionais despreparados & 2 & 1 & 0 \\
\hline O Brasil não é um país racista & 2 & 4 & 0 \\
\hline AAR fracassou em outros lugares & 2 & 1 & 0 \\
\hline $\begin{array}{l}\text { Não há o que reparar, pois todo brasileiro é } \\
\text { afrodescendente }\end{array}$ & 2 & 3 & 0 \\
\hline Pobreza dos negros não se deve à discriminação & 2 & 6 & 0 \\
\hline Não há ainda resultados positivos conclusivos & 1 & 8 & 2 \\
\hline $\begin{array}{l}\text { AAR resulta da captura do Estado por movi- } \\
\text { mentos sociais }\end{array}$ & 1 & 2 & 0 \\
\hline AAR é uma política neoliberal & 1 & 2 & 0 \\
\hline AAR tende a se perpetuar & 1 & 3 & 0 \\
\hline AAR provoca ressentimento nos brancos & 1 & 4 & 0 \\
\hline Não há negros para preencher as vagas & 1 & 0 & 0 \\
\hline Racismo oculto é melhor que explícito & 0 & 1 & 0 \\
\hline AAR dá margem a abuso de poder & 0 & 1 & 0 \\
\hline AAR rompe com republicananismo brasileiro & 0 & 0 & 0 \\
\hline Não é função da universidade estabelecer AARs & 0 & 4 & 0 \\
\hline Total & 468 & 246 & 19 \\
\hline
\end{tabular}


Quadro 2: Justificações favoráveis

\begin{tabular}{|c|c|c|c|}
\hline & Mídia & $\begin{array}{l}\text { Audiência } \\
\text { Pública }\end{array}$ & Acórdão \\
\hline AAR inclui os excluídos (genérico) & 48 & 39 & 14 \\
\hline AAR diminui as desigualdades (genérico) & 36 & 41 & 12 \\
\hline $\begin{array}{l}\text { AAR repara erros cometidos no passado } \\
\text { (genérico) }\end{array}$ & 25 & 33 & 4 \\
\hline $\begin{array}{l}\text { AAR é medida emergencial diante de uma situa- } \\
\text { ção crítica }\end{array}$ & 24 & 15 & 3 \\
\hline AAR instaura a igualdade de oportunidades & 22 & 28 & 7 \\
\hline $\begin{array}{l}\text { AAR introduz pluralidade nas instituições } \\
\text { (empresas, universidades etc.) }\end{array}$ & 16 & 9 & 4 \\
\hline $\begin{array}{l}\text { AAR combate o racismo/discriminação } \\
\text { (genérico) }\end{array}$ & 13 & 33 & 9 \\
\hline $\begin{array}{l}\text { AAR inclui os beneficiários nos níveis mais altos } \\
\text { da sociedade }\end{array}$ & 9 & 4 & 4 \\
\hline AAR realiza o mérito & 8 & 1 & 2 \\
\hline $\begin{array}{l}\text { AAR realiza o princípio da igualdade formal de } \\
\text { tratamento }\end{array}$ & 8 & 26 & 19 \\
\hline $\begin{array}{l}\text { AAR tem estimulado o debate sobre as desigual- } \\
\text { dades raciais }\end{array}$ & 7 & 14 & 6 \\
\hline AAR diminui as desigualdades socioeconômicas & 7 & 21 & 4 \\
\hline $\begin{array}{l}\text { AAR é uma forma de dirimir os efeitos da escra- } \\
\text { vidão no presente }\end{array}$ & 7 & 18 & 9 \\
\hline $\begin{array}{l}\text { AAR combate o racismo/discriminação institu- } \\
\text { cional ou estrutural }\end{array}$ & 6 & 21 & 7 \\
\hline $\begin{array}{l}\text { AAR promove a mobilidade social de grupos } \\
\text { discriminados }\end{array}$ & 6 & 15 & 7 \\
\hline $\begin{array}{l}\text { AAR reconhece a diversidade cultural brasileira } \\
\text { (genérico) }\end{array}$ & 6 & 11 & 3 \\
\hline AAR teve êxito em outros lugares & 6 & 9 & 3 \\
\hline Há sinais de sucesso da AAR no Brasil & 6 & 19 & 10 \\
\hline
\end{tabular}




\begin{tabular}{l|c|c|c}
\hline & Mídia & $\begin{array}{c}\text { Audiência } \\
\text { Pública }\end{array}$ & Acórdão \\
\hline $\begin{array}{l}\text { AAR capacitará os beneficiários a competir em } \\
\text { pé de igualdade }\end{array}$ & 6 & 4 & 3 \\
\hline AAR inclui potenciais antes desperdiçados & 4 & 7 & 4 \\
\hline AAR introduz os beneficiários na cidadania & 3 & 9 & 9 \\
\hline $\begin{array}{l}\text { AAR é uma forma de “indenização” aos que } \\
\text { foram escravizados }\end{array}$ & 3 & 14 & 7 \\
\hline $\begin{array}{l}\text { AAR reconhece/denuncia o preconceito até então } \\
\text { encoberto }\end{array}$ & 3 & 9 & 2 \\
\hline AAR cria uma classe média negra & 3 & 49 & 31 \\
\hline AAR efetiva princípios constitucionais & 3 & 2 & 1 \\
\hline $\begin{array}{l}\text { AAR reconhece a contribuição histórico-cultural } \\
\text { dos grupos marginalizados }\end{array}$ & 2 & 14 & 6 \\
\hline AAR realiza um projeto de nação & 2 & 12 & 9 \\
\hline AAR é decisiva para a integração nacional & 2 & 8 & 0 \\
\hline AAR aumentará a autoestima dos beneficiários & 1 & 0 & 0 \\
\hline AAR consolida/realiza princípios republicanos & 0 & 12 & 5 \\
\hline $\begin{array}{l}\text { AAR combate o racismo/discriminação nas rela- } \\
\text { A̧os sociais entre indivíduos }\end{array}$ & 0 & 19 & 7 \\
\hline AAR dissocia cor de pobreza & 0 & 12 & 4 \\
\hline TAR produz prosperidade/eficiência econômica & 0 & 8 & 4 \\
\hline
\end{tabular}

